\title{
Pediatrični medicinski stres in travma
}

\author{
Jana Škorjanc ${ }^{*}$, Ivana Kreft Hausmeister ${ }^{2}$ in Sandra Klašnja ${ }^{2}$ \\ ${ }^{1}$ Center za sluh in govor Maribor \\ ${ }^{2}$ Klinični oddelek za otroško hematologijo in onkologijo, Pediatrična klinika, Univerzitetni klinični center Ljubljana
}

Povzetek: Dogodki, povezani z različnimi boleznimi, poškodbami in kroničnimi stanji ter z njimi povezano zdravljenje in medicinske intervencije, predstavljajo najpogostejše potencialne travmatske izkušnje v otroštvu. $\mathrm{V}$ članku se avtorice sprašujemo o pojavu travmatskega stresa in medicinske travme pri otrocih in njihovih družinah. Pri prepoznavanju medicinske travme si lahko pomagamo $\mathrm{s}$ teoretičnim modelom dolgotrajne somatske grožnje, ki je bil oblikovan z namenom razločevanja med medicinsko in nemedicinsko travmo (ki je niso povzročili medicinski dogodki). Različne raziskave poročajo, da kar do $80 \%$ otrok in njihovih družin doživlja nekoliko travmatskega stresa pri soočanju z življenjsko ogrožajočimi boleznimi, poškodbami ali bolečimi medicinskimi postopki. Približno 20-30 \% staršev ter 15-25 \% otrok in njihovih sorojencev pa celo doživlja trajen travmatski stres, ki ovira vsakodnevno delovanje in vpliva na sam potek zdravljenja ter okrevanja. Razvoj in potek pediatrične medicinske travme ponazarja model pediatričnega medicinskega travmatskega stresa, ki za posamezno fazo poteka navaja tudi cilje intervencij. Poleg psihologa ima pri preprečevanju travme, ki se lahko pojavi pri obravnavi otrok, mladostnikov in njihovih staršev, pomembno vlogo tudi zdravstveno osebje. Vsi strokovni oziroma zdravstveni delavci si moramo prizadevati, da obravnava in oskrba otrok vključuje zavedanje in ozaveščanje o travmi. Na ta način lahko namreč pomembno preprečimo ali zmanjšamo negativne posledice travme, do katere lahko pride $\mathrm{v}$ medicinskem okolju.

Ključne besede: otroci, starši, medicinska travma, rak, intenzivna nega

\section{Pediatric medical stress and trauma}

\author{
Jana Škorjanc ${ }^{*}$, Ivana Kreft Hausmeister ${ }^{2}$ and Sandra Klašnja ${ }^{2}$ \\ ${ }^{1}$ Center for Hearing and Speech Maribor, Slovenia \\ ${ }^{2}$ Clinical department for Children's Hematology and Oncology, Pediatric Clinic,University Medical Center Ljubljana, Slovenia
}

\begin{abstract}
Events related to various illnesses, injuries and chronic conditions, as well as related treatment and medical interventions, represent the most common potential traumatic experiences in childhood. In the article, the author inquires about the occurrence of traumatic stress and medical trauma in children and their families. A theoretical model of long-term somatic threat designed to distinguish between medical trauma and trauma not caused by medical events can be used to identify medical trauma. Various studies report that up to $80 \%$ of children and their families experience some traumatic stress in dealing with life-threatening illnesses, injuries or painful medical procedures. About $20-30 \%$ of parents and $15-25 \%$ of children and their relatives even experience lasting traumatic stress that impedes daily functioning and affects the very course of treatment and recovery. The development and course of pediatric medical trauma is exemplified by the model of pediatric medical traumatic stress, which also outlines the goals of interventions for each stage of the course. In addition to the psychologist, health care staff also play an important role in preventing the trauma that can occur when treating children, adolescents and their parents. All professionals and healthcare professionals should strive to address and care for children, including awareness of and informing about trauma, and thus prevent or reduce the negative effects of trauma that can occur in the medical environment.
\end{abstract}

Keywords: children, adolescents, parents, medical trauma, cancer, intensive care

\footnotetext{
"Naslov/Address: Jana Škorjanc, Center za sluh in govor Maribor, Vinarska 6, 2000 Maribor, e-mail: jana.skorjanc@csgm.si

Članek je licenciran pod pogoji Creative Commons Attribution 4.0 International licence. (CC-BY licenca).

The article is licensed under a Creative Commons Attribution 4.0 International License (CC-BY license).
} 
Pri delu v zdravstvenih ustanovah se zaposleni srečujemo $\mathrm{z}$ otroki in njihovimi družinami, ki jih $\mathrm{k}$ nam pripeljejo različne bolezni in poškodbe, torej okoliščine, ki so neugodne, neprijetne, boleče, v najtežjih primerih celo življenjsko ogrožajoče. Z napredkom v medicinski diagnostiki in oskrbi se preživetje pri pediatričnih boleznih in kroničnih stanjih v zadnjih štirih desetletjih stalno povečuje, kar je pripeljalo do spoznanja, da obstajajo medicinski, funkcionalni in drugi zdravstveni učinki, ki presegajo samo bolezen, vključno $\mathrm{s}$ povezanimi psihološkimi posledicami. To spoznanje je odprlo novo področje preučevanja, ki ob bok zdravljenju postavlja kakovost življenja bolnega otroka in njegove družine. Vključuje razmišljanje o dolgoročnih posledicah življenjsko ogrožajoče ali kronične bolezni ter poteka zdravljenja. Vsi dogodki povezani s poškodbami, akutnimi medicinskimi stanji, boleznijo in posledično potrebnimi medicinskimi intervencijami ter zdravljenjem, sodijo med najpogostejše in potencialne travmatske situacije $\mathrm{v}$ otroštvu (Pai in Kazak, 2006).

V članku avtorice opredelimo pediatrični medicinski travmatski stres, opišemo doživljanje otrok po travmatskem medicinskem dogodku, razmejimo medicinsko od nemedicinske travme in predstavimo psihološke intervencije

\section{Opredelitev pediatričnega medicinskega travmatskega stresa}

Pediatrični medicinski travmatski stres (angl. pediatric medical traumatic stress [PMTS]) obsega niz psiholoških in fizioloških odzivov otrok in njihovih družin na bolečino, poškodbe, hudo bolezen, medicinske postopke in invazivne, tudi zastrašujoče izkušnje z zdravljenjem (National Child Traumatic Stress Network, 2003). Vključuje odzive, kot so vzburjenost, podoživljanje in izogibanje, ki se lahko razlikujejo v intenziteti in motijo posameznikovo delovanje. Torej gre za akutno stresno reakcijo otroka ali njegove družine na medicinski poseg ali drugo izkušnjo, povezano z zdravljenjem. Pojavi se lahko kot odziv na en sam ali na več medicinskih dogodkov, ki ga otrok doživi kot izredno stresnega, travmatskega. $\mathrm{V}$ tem primeru lahko govorimo o medicinski travmi.

Večina pediatričnih pacientov in njihovih družin je pri soočenju z boleznijo kompetentna, prožna in se nastali situaciji ustrezno prilagodi (Kazak idr., 2007). V primeru, da se otrok ali družina nastali situaciji ne prilagodijo, se odzivi na izjemno hud, življenjsko ogrožajoč dogodek odražajo predvsem na ravni podoživljanja, izogibanja in pretiranega vzburjenja. Pomembno je opozoriti, da vse omenjene reakcije predstavljajo normalen in pričakovani odziv ob pojavu stresnega dogodka, saj predstavljajo način soočenja Z negativnimi izkušnjami. V primeru klinično pomembnega stopnjevanja težav pa lahko po diagnostičnih kriterijih DSM-5 opredelimo posttravmatsko stresno motnjo (American Psychiatric Association, 2013). Posttravmatska stresna motnja predstavlja intenzivno tesnoben odziv, ki vključuje epizode ponovnega doživljanja travme $\mathrm{v}$ obliki vsiljivih spominov, misli, sanj in nočnih mor, čustveno otopelost in odtujenost od drugih ljudi, anhedonijo in izogibanje dejavnostim ter okoliščinam, ki spominjajo na travmo, stanje avtonomne vzdraženosti, razdražljivosti, povečano vznemirjenje in tesnobo. O posttravmatski stresni motnji govorimo, kadar so vsi omenjeni simptomi prisotni več kot mesec dni in pomembno ovirajo delovanje na več področjih posameznikovega življenja. V primeru da simptomi, kot so občutek nemira, pretirane vzburjenosti, strahu, izogibanje situacijam, ki spominjajo na dogodek, podoživljanje in slaba koncentracija vztrajajo, vendar ne dosegajo ravni klinične izraženosti, pa govorimo o posttravmatskem stresnem sindromu (PTSS). Ob tem ločimo še akutno stresno reakcijo, katero opredelimo, ko se že opisani simptomi - predvsem razmišljanje o travmatičnem dogodku, nočne more, povišani fiziološki odzivi, izogibanje pogovoru in razmišljanju o dogodku, izogibanje aktivnostim, prostoru in ljudem ter pretirano vzburjenje in občutki strahu - umirijo dokaj hitro, v roku dveh tednov oziroma $\mathrm{v}$ manj kot mesecu dni.

PMTS ni omejen na diagnostični entiteti akutna stresna reakcija in posttravmatska stresna motnja, saj specifični pogoji omenjenih diagnoz niso povsem $\mathrm{v}$ skladu $\mathrm{s}$ fenomenologijo odzivov otrok in njihovih staršev na medicinske dogodke. Zato $\mathrm{v}$ primeru PMTS govorimo o posttravmatskih stresnih simptomih, ki predstavljajo ključne simptome posttravmatske stresne motnje (vzburjenje, podoživljanje, izogibanje), ne da bi posameznik dosegal celotne diagnostične kriterije za akutno stresno reakcijo ali posttravmatsko stresno motnjo (Pai in Kazak, 2006). Opredelitev je pomembna zaradi zgodnje intervencije, ki lahko prepreči razvoj motnje.

\section{Odziv otroka na travmatski dogodek}

Otroci se na travmatski dogodek odzovejo drugače kot odrasli. Na podlagi predstavljene teorije njihov odziv vključuje pojav kompulzivnega, ponavljajočega se vedenja, regres na zgodnejše oblike vedenja, izbruhe togote, nekontrolirane napade jeze, hiperaktivnost, po drugi strani pa tudi plašljivost, sramežljivost in umik, izrazito potrebo po iskanju varnosti in ločitveno tesnobo. Pogosto so prisotni ponavljajoči se nočne more in strahovi, nemirno spanje, lahko pa tudi močenje postelje, bolečine v trebuhu, glavoboli in druge bolečine brez pojasnjenega medicinskega izvora. Pri starejših otrocih lahko opazimo pozabljivost in nezmožnost zbranosti v šoli ali pri drugih dejavnostih (Levine in Frederick, 1997). Dovzetnost za travmo se od otroka do otroka razlikuje, saj je odvisna od spola (deklice so bolj ogrožene), starosti (mlajši otroci so bolj ogroženi), kakovosti zgodnjih vzorcev navezanosti, zgodovine travmatskih izkušenj, genetskih predispozicij in značilnosti družine - odziv staršev na nastalo situacijo in njihov stil soočenja s stresom (Ben-Ari idr., 2019; Bokszczanin, 2007; Meiser-Stedman idr., 2006; Ostrowski idr., 2007). Mlajši kot je otrok, bolj je verjetno, da ga bodo preplavili običajni dogodki, ki starejšega otroka ali odraslega ne bi tako prizadeli (Levine in Kline, 2018).

\section{Dejavniki tveganja za razvoj medicinske travme}

Medicinska travma se torej pojavi v neposrednem stiku z medicinskim okoljem. Razvije se preko zapletenih interakcij med pacientom, zdravstvenim osebjem, medicinskim okoljem 
in diagnozo ali zdravstvenim posegom, ki ima lahko učinek na bolnikovo edinstveno oziroma subjektivno interpretacijo dogodka (Hall in Hall, 2016). Odzivi otroka na medicinsko travmo so pogosto bolj povezani s subjektivnimi izkušnjami $\mathrm{s}$ posegom ali z zdravljenjem kot $\mathrm{z}$ objektivno resnostjo leteh. Obravnava je vedno vezana na kontekst celotne družine, saj se otrok mlajši od 15 let ne more sam odločati o posegih in zdravljenju, ampak te odločitve zanj sprejemajo drugi (Pai in Kazak, 2006).

Na medicinsko travmo moramo gledati kot na kontinuum, ki se lahko pojavi na kateri koli točki procesa pacientove oskrbe. Specifične medicinske izkušnje razvrščamo na tri ravni, ki se gibljejo od večje do manjše ogroženosti življenja. Tretja, najvišja raven se nanaša na urgentna stanja, druga raven na življenjsko ogrožajoče in življenjsko spreminjajoče se bolezni ter prva, najnižja raven, na načrtovano in rutinsko zdravstveno oskrbo. Omenjene tri ravni so med seboj pretočne, med posameznimi nivoji je možen tudi hiter prehod.

Razvoj medicinske travme je odvisen tudi od okolja. Pogosto se zdravstveni timi osredotočamo na specifične dejavnike, kot so obstoječe težave $\mathrm{z}$ duševnim zdravjem, zgodovina travmatskih izkušenj in osebnostne lastnosti posameznika, pri tem pa lahko spregledamo, da medicinska izkušnja ni travmatična le zaradi posameznikove ranljivosti oziroma predispozicijskih lastnosti, temveč obstaja še vrsta drugih pomembnih dejavnikov, kot je tudi kontekst medicinskega okolja (npr. osvetlitev prostorov, neznani in zastrašujoči predmeti, različni zvoki, vonjave, neudobna oprema). Poleg tega moramo biti pozorni na protokole, ki prispevajo $\mathrm{k}$ pacientovim občutkom ranljivosti (npr. čakanje na poseg le v halji brez lastnih oblačil). Pomemben dejavnik je tudi odnos in način komunikacije zdravstvenega osebja z otrokom ter njihova občutljivost do edinstvene situacije, v kateri se je le-ta znašel. To vpliva na otrokove izkušnje $z$ določenim posegom ali trajajočo oskrbo zaradi kronične bolezni (Hall in Hall, 2016).

\section{Model dolgotrajne somatske grožnje}

Model dolgotrajne somatske grožnje (angl. Enduring somatic threat model) je teorija, ki loči medicinsko travmo od travme, ki je niso povzročili medicinski dogodki (nemedicinska travma). Oblikovan je bil z namenom razlage neprijetnih psiholoških in vedenjskih posledic, ki pogosto sledijo življenje ogrožajočim boleznim in jih trenutno uvrščamo med simptome posttravmatske stresne motnje (Edmondson, 2014).

Model temelji na treh predpostavkah. Prva predpostavka se nanaša na izvor travme, torej na sprožilni dogodek (Edmondson, 2014). Za nemedicinsko travmo je značilno, da grožnja prihaja iz posameznikovega okolja; travmatičen dogodek se je zgodil v preteklosti in se tam tudi zaključil. $\mathrm{V}$ tem primeru torej govorimo o diskretnih dogodkih $\mathrm{z}$ zunanjimi sprožilci. Življenje ogrožajoča bolezen, pa je pogosto akutna manifestacija trajne motnje fiziološkega sistema, katere posledice so lahko prisotne tudi leta kasneje, saj je grožnja (npr. huda bolezen, bolečina ali smrt) locirana $\mathrm{v}$ posameznikovem telesu. Omenjeno lahko ponazorimo $\mathrm{s}$ primerom onkološkega bolnika. Izkušnje otroka z rakom se običajno začnejo s sumljivimi izvidi, ki jim sledijo podrobne preiskave, opredelitev diagnoze in dolgotrajno zdravljenje, ki je lahko zelo invazivno in boleče. Po zaključenem intenzivnem zdravljenju pri mnogih otrocih sledi vzdrževalno zdravljenje in redni onkološki pregledi še leta po zaključenem zdravljenju. Travmatske značilnosti raka ne odražajo grožnje diskretnega dogodka, temveč izvirajo iz dolgoletnih izkušenj ranljivosti, bolečine in strahu. Poleg tega je narava bolezni taka, da je neprestana pozornost in pazljivost do grožnje lahko tudi zaželena, saj obstaja verjetnost ponovitve bolezni. Želeni izid za posameznike z nemedicinsko travmo je zmanjšati čustveno vsebino spominov, vezanih na diskreten travmatičen dogodek in prestaviti ta dogodek na nek drug spomin iz preteklosti. Pacienti z življenjsko ogrožajočo boleznijo pa morajo ta travmatski dogodek postaviti kot gonilo njihovih vsakodnevnih aktivnosti, kar pomeni, da morajo neprestano nadzirati grožnjo s spremembami življenjskega sloga, zdravili in interakcijami z zdravstvenim sistemom. Vse to pa so opomniki neprestane ranljivosti in izvora travme, kar je za posameznike lahko zelo zaskrbljujoče, stresno ter povezano s slabšim psihološkim prilagajanjem pri otrocih z rakom. Diskretna nemedicinska travma torej izvira iz posameznikove okolice, iz katere se posameznik lahko umakne $\mathrm{v}$ varno okolje, si opomore in ponovno vzpostavi obstoječe življenjske vzorce. Pri posameznikih $\mathrm{z}$ življenje ogrožajočo boleznijo pa je izvor travme $\mathrm{v}$ posameznikovem telesu, torej kot tak vedno prisoten.

Druga predpostavka modela se nanaša na edinstvene značilnosti simptomov medicinsko povzročene posttravmatske stresne motnje (Edmondson, 2014). Medicinski dogodki sprožijo odziv pretiranega in neprilagodljivega strahu na resnično in dolgotrajno grožnjo posameznikovega obstoja. Torej je pri posameznikih z življenje ogrožajočo boleznijo odziv strahu na stalno, somatsko grožnjo smrti trajen in včasih tudi realen. Medtem ko odziv na nemedicinski, pretekli, diskretni, zunanji dogodek upravičeno predstavlja grožnjo smrti $\mathrm{v}$ preteklosti, tako da lahko posameznik ponovno vzpostavi normativni odnos do smrti kot nekaj, kar se bo zgodilo nekje v daljni prihodnosti.

Medtem ko omenjeni predpostavki modela govorita o razlikah, tretja predpostavka govori o tem, da je osnovni vir stresa pri obeh oblikah travme zastrašujoče zavedanje smrtne nevarnosti (Edmondson, 2014).

Model dolgotrajne somatske grožnje (slika 1) predstavlja edinstvene fiziološke in vedenjske izzive, povezane $\mathrm{s}$ psihološkim in medicinskim vodenjem otrok $\mathrm{s}$ posttravmatsko stresno motnjo zaradi soočanja z življenje ogrožajočo boleznijo. Čeprav obstaja več osebnostnih (npr. nevroticizem), psiholoških (npr. predhodna tesnoba ali motnje razpoloženja), demografskih in socialnih oziroma situacijskih dejavnikov (npr. konflikti v družini, težave v šoli, težave z vrstniki), ki povečujejo dovzetnost posameznikov, da razvijejo posttravmatsko stresno motnjo zaradi medicinskega dogodka, so omenjeni dejavniki tudi napovedniki posttravmatske stresne motnje zaradi nemedicinskega, diskretnega, zunanjega travmatičnega dogodka, zaradi česar se zdi, da ne omogočajo nazornega in edinstvenega vpogleda $\mathrm{v}$ medicinsko travmo. Posledično model predpostavlja, da je posameznikovo subjektivno 


\section{Slika 1}

Model dolgotrajne somatske grožnje

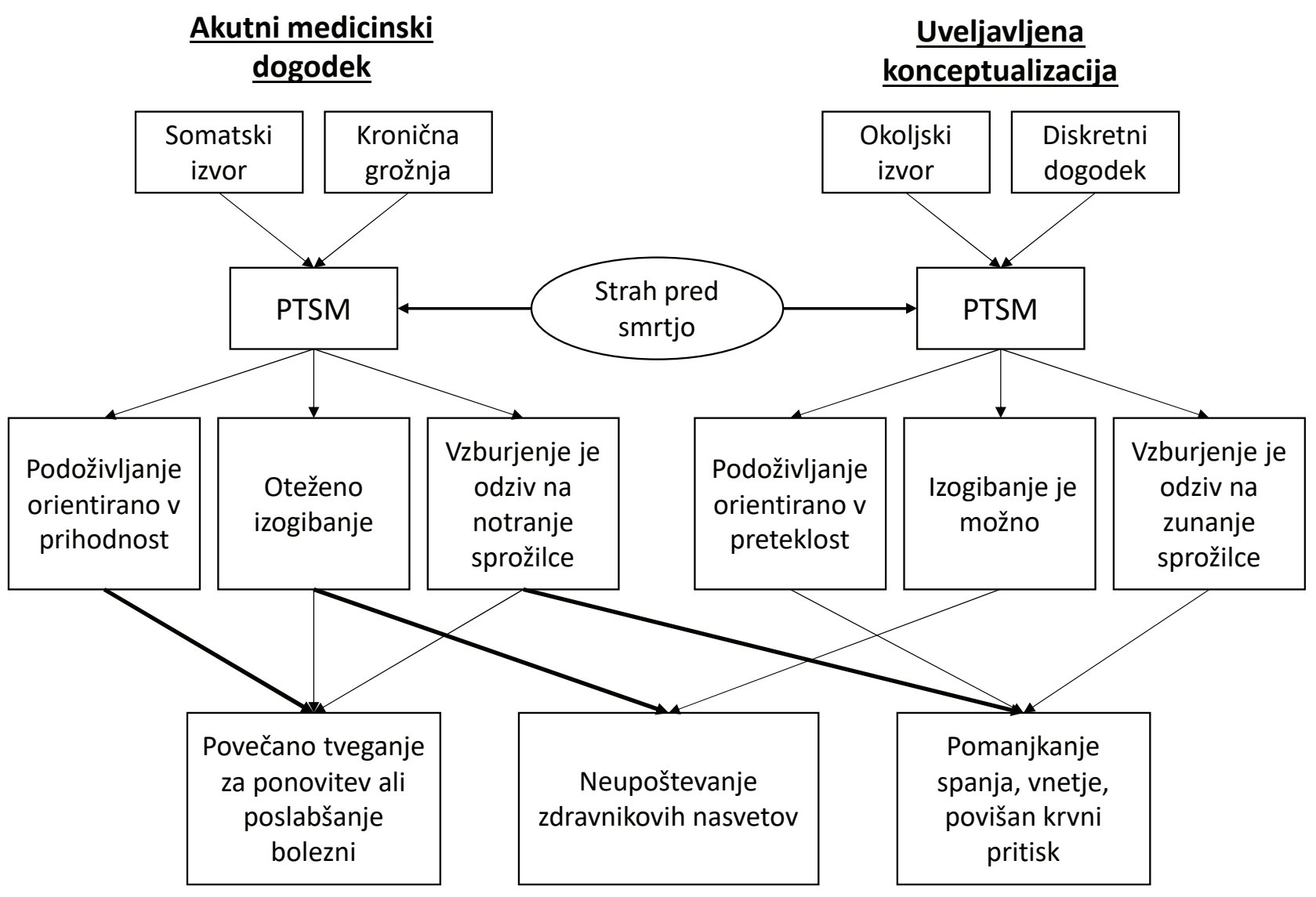

Opomba: Povezave med vedenjem in zdravstvenim stanjem so ponazorjene s puščicami, pri čemer temnejše puščice predstavljajo močne in konsistentne empirične dokaze, svetlejše puščice pa povezave z nekoliko manj empiričnimi dokazi.

doživljanje stopnje življenjske ogroženosti na začetku medicinskega dogodka eden glavnih napovednikov kasnejšega razvoja posttravmatske stresne motnje. Poleg tega naj bi medicinska prognoza pomagala določiti resnost in trajanje simptomov posttravmatske stresne motnje. Pogostejše doživljanje somatskih simptomov, ki lahko posameznika opomnijo na pretečo smrt, pa naj bi tudi napovedovali pogostost, resnost in trajanje simptomov posttravmatske stresne motnje (Edmondson, 2014).

$\mathrm{Za}$ osebe s posttravmatsko stresno motnjo je značilna povečana fiziološka reaktivnost in zavedanje somatskih kazalcev bolezni, zaradi česar se poskušajo izogniti situacijam, ki jih opominjajo na travmo, s pomočjo kognitivnega ali vedenjskega odklopa (npr. preusmeritev pozornosti, zloraba substanc) in z izogibanjem dogodkom, povezanim z medicinskim okoljem. Če je prisotno takšno izogibajoče se vedenje pri posamezniku ali v primeru bolnega otroka pri njegovih starših, bodo le-ti izpostavljeni večjemu tveganju za ponovitev ali poslabšanje bolezni, saj ne bodo deležni standardne zdravstvene obravnave. Situacije, vezane na zdravljenje, za njih predstavljajo močan opomnik izvornega travmatskega dogodka in neprestane somatske grožnje zaradi posameznikove bolezni (Edmondson, 2014).

\section{Prevalenca pediatričnega medicinskega travmatskega stresa}

Po podatkih Ameriškega nacionalnega združenja otrok z izkušnjo travmatskega stresa do $80 \%$ otrok in njihovih družin doživlja del travmatskega stresa pri soočanju $\mathrm{Z}$ življenje ogrožajočimi boleznimi, poškodbami ali bolečimi medicinskimi postopki (National Child Traumatic Stress Network, 2003). V različnih raziskavah so ugotovili, da 20-30 \% staršev ter 15-25\% otrok in njihovih sorojencev doživlja trajen travmatski stres, ki ovira vsakodnevno delovanje in vpliva na sam potek zdravljenja ter okrevanja.

Pediatrične poškodbe in rak predstavljajo najvišjo prevalenco pediatričnega medicinskega travmatskega stresa. PMTS je prisoten pri $8-75 \%$ otrok, ki so preboleli rak, in pri 20-22\% njihovih staršev glede na metaanalizo raziskav s področja pediatričnega medicinskega travmatskega stresa. Stopnja le-tega je višja pri starših otrok obolelih za rakom, v primerjavi s tistimi po poškodbi. Primerjava različnih zdravstvenih stanj in postavljenih diagnoz (rak, sladkorna bolezen in resnejše poškodbe) kaže, da čeprav so otroci pogosto deležni podobnih medicinskih dogodkov (hospitalizacija, intenzivna nega in boleči medicinski posegi), so ti medicinski dogodki pogostejši in intenzivnejši 


\section{Tabela 1}

Delež posttravmatske stresne motnje (PTSM) in posttravmatskega stresnega sindroma pri otrocih (PTSS)

\begin{tabular}{lcc}
\hline Medicinski dogodek & PTSS (\%) & PTSM (\%) \\
\hline Rak & 12 & $20-35$ \\
$\begin{array}{l}\text { Travmatske telesne poškodbe, } \\
\text { opekline, transplantacije }\end{array}$ & 19 & 42 \\
\begin{tabular}{l} 
Enota za intenzivno nego \\
\hline
\end{tabular} & $35-62$ & $5-28$ \\
\hline
\end{tabular}

oziroma precej bolj stresni za otroke, ki imajo diagnozo rak ali so poškodovani, kot pa za otroke, ki se soočajo s sladkorno boleznijo (Price idr., 2015).

Starši otrok, s prvič diagnosticiranim rakom in tistih, ki jih čaka presaditev organa, zaznavajo večjo ogroženost življenja njihovih otrok in tudi zdravljenje zaznavajo kot bolj intenzivno in zapleteno, $v$ primerjavi s starši otrok, ki so zboleli za virusom humane imunske pomanjkljivosti (HIV), boleznijo srpastih celic, sladkorno boleznijo ali so utrpeli nenamerno poškodbo (Price idr., 2015). Podoben delež staršev poroča o visoki stopnji vztrajajočega distresa, ki moteče vpliva na družinsko življenje, delovno učinkovitost in na doseganje zahtev zdravljenja (Ingerski idr., 2010).

Lahko zaključimo, da relativno majhen delež otrok in staršev doseže klinično pomembne kriterije za diagnozo posttravmatske stresne motnje, vendar pa jih precejšen delež doživlja posttravmatske stresne simptome (Ingerski idr., 2010).

$\mathrm{V}$ prvih 2 tednih po postavljeni diagnozi rak več kot $50 \%$ mater in $40 \%$ očetov kaže znake akutne stresne motnje (Patino-Fernandez idr., 2007). Simptomi akutnega stresa so torej v veliki meri prisotni tako pri materah kot očetih otrok, obolelih za rakom, v obdobju takoj po postavljeni diagnozi. Delež staršev, ki dosegajo diagnostične kriterije za akutno stresno motnjo, je precej večji kot pri drugih skupinah staršev otrok, obolelih za drugo pediatrično boleznijo (McCarthy idr., 2012). V obdobju 6-8 tednov po diagnozi pa približno ena petina staršev dosega diagnostične kriterije za posttravmatsko stresno motnjo, kar je nekoliko manjši delež staršev kot v akutni fazi, torej takoj po diagnozi. Nekatere simptome posttravmatske stresne motnje pa doživlja $46 \%$ mater in $28 \%$ očetov (McCarthy idr., 2012). Še posebej ima otrokova bolezen vpliv na matere, saj v večji meri poročajo o psihološkem distresu v primerjavi $\mathrm{z}$ materami zdravih otrok in očeti otrok z rakom-(Pai idr., 2007). Metaanalize prav tako kažejo na različno pojavnost posttravmatske stresne motnje in posttravmatskega stresnega sindroma glede na različne kontekste in postavljene diagnoze pri otrocih, kot prikazuje tabela 1 (Marsac idr., 2014; Nelson in Gold, 2012).

$\mathrm{V}$ metanalizi raziskav je zaslediti, da je prevalenca posttravmatske stresne motnje višja po akutni obravnavi na pediatrični intenzivni enoti $\mathrm{v}$ primerjavi s splošnim kliničnim oddelkom. Pri tem $21 \%$ otrok in $27 \%$ staršev dosega diagnostične kriterije za posttravmatsko stresno motnjo (Rees idr., 2004). Negativne psihološke posledice lahko pridejo do izraza $\mathrm{v}$ prvem letu po odpustu iz enote za intenzivno nego (Rennick in Rashotte, 2009). Prav tako je prevalenca višja pri nepričakovanih, nenadnih hospitalizacijah in življenje ogrožajočih stanjih. Otroci, ki so izpostavljeni večkratnim invazivnim posegom in daljši hospitalizaciji, so prav tako bolj ogroženi za razvoj posttravmatske stresne motnje (Rennick idr., 2004).

Več kot tretjina otrok, starejših od osem let, ima subklinično sliko posttravmatske stresne motnje tri mesece po odpustu iz enote za intenzivno nego, medtem ko eden izmed sedmih otrok dosega diagnostične kriterije za posttravmatsko stresno motnjo (Bronner idr., 2008). V opazovalni študiji, izvedeni na prostoru Evropske unije (Jones idr., 2007), je bil delež prevalence posttravmatske stresne motnje 9,2\%. Avtorji torej ugotavljajo, da obstaja 1:10 možnosti, da otroci ali odrasli razvijejo posttravmatsko stresno motnjo po zdravljenju na enoti za intenzivno nego. Kljub temu da je večina zdravljenih oseb na enoti za intenzivno nego odpornih ali si opomorejo brez klinično pomembnih stresnih simptomov, je izrednega pomena, da prepoznamo dejavnike tveganja za razvoj posttravmatske stresne motnje in jih skušamo zmanjšati s pomočjo preventivnih intervencij in programov (Bronner idr., 2008).

\section{Model pediatričnega medicinskega travmatskega stresa}

Uporaba pojma travma v kontekstu pediatrične obravnave predstavlja premik izven konteksta travmatskih stresnih motenj. Na podlagi kliničnih izkušenj in raziskav je tako avtorica Anne Kazak s sodelavci (2006) razvila Model pediatričnega medicinskega travmatskega stresa, ki vključuje kontinuum glavnih simptomov posttravmatske stresne motnje, kot so pretirano vzburjenje, podoživljanje in izogibanje, ki pa ne dosegajo nujno klinične izraženosti posttravmatske stresne motnje $\mathrm{v}$ kontekstu pediatrične obravnave. Predstavljen model je torej eden prvih, ki se osredotoča na izkušnjo otrok in staršev $\mathrm{v}$ medicinskem kontekstu ter predlaga ključne intervencije.

Model obsega tri faze. Vsaka od njih predstavlja odsek izkušnje otroka in družine $s$ potencialno travmatskim medicinskim dogodkom. Vsaka faza ustreza določenemu časovnemu obdobju, in sicer prva faza vključuje pojav potencialno travmatskega dogodka (slika 2: PTD oziroma $\mathrm{v}$ angleščini potentially traumatic event [PTE]) in njegove takojšnje posledice. Druga faza zajema zgodnji, akutni ter stalni in razvijajoči se travmatski stresni odziv, ki se odvija vzporedno s fizičnimi posledicami bolezni in zdravljenja. Zadnja, tretja faza pa vključuje dolgotrajnejše travmatske odzive, kot so neposredne telesne posledice, ko je samo zdravljenje že zaključeno in akutna nevarnost odpravljena. Model predpostavlja, da se sam čas in trajanje posamezne faze razlikuje glede na potek zdravstvenega stanja posameznega otroka. Pri tem se je pomembno zavedati, da se potencialni travmatski dogodki, ki pomembno vplivajo na subjektivno izkušnjo same bolezni, zdravljenja in vseh potrebnih posegov, lahko ponovijo, kar predstavlja večjo verjetnost za pojav kasnejših epizod travme (Kazak idr., 2006).

$\mathrm{V}$ okviru prve faze, ki jo imenujejo faza peri-travme, je ključen predvsem tako imenovani potencialni travmatski dogodek, kjer je poudarek na subjektivni izkušnji otroka in 


\section{Slika 2}

Model pediatričnega medicinskega travmatskega stresa (Kazak idr., 2006)

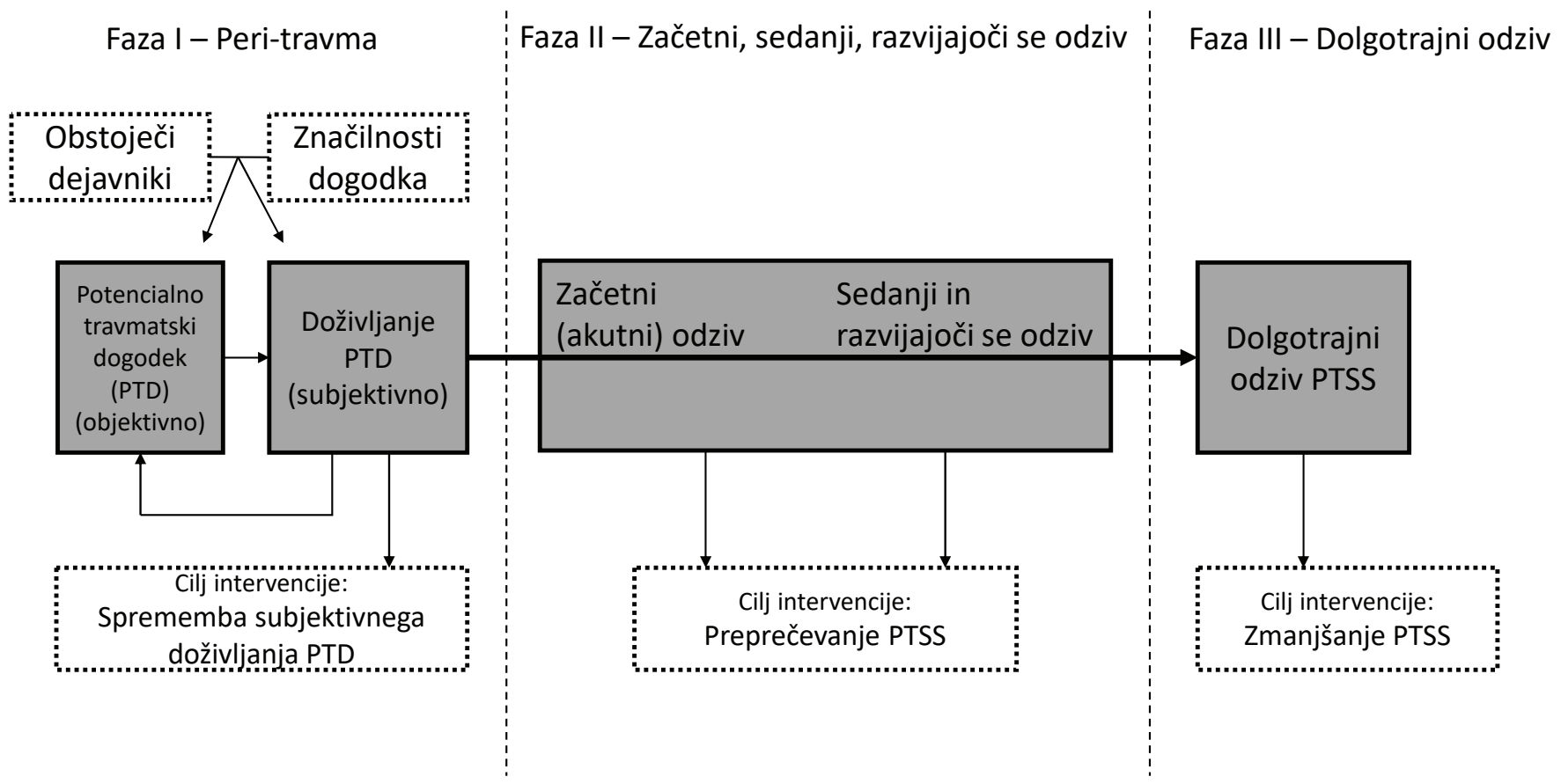

staršev. Ob tem se pojavijo predvsem občutki ogroženosti, nemoči in strahu. Pomembno vlogo za doživljanje potencialno travmatskega dogodka imajo že obstoječi dejavniki, kot so sposobnost prilagajanja na stresne situacije, stili soočenja s stresom, prisotnost anksiozno-depresivne simptomatike ter prisotnost psihopatologije $\mathrm{v}$ družini. Pomembna je tudi podpora širše družine in druge oblike podpore iz okolja. Poleg že obstoječih dejavnikov pa na doživljanje posameznika vplivajo tudi same značilnosti dogodka, kot so objektivna resnost bolezni, stanje otroka in s tem povezani medicinski posegi. Cilj na tej fazi je zgodnje prepoznavanje potencialno travmatskega dogodka in predvsem delovanje na nivoju preventive (Kazak idr., 2006).

V okviru druge faze, ki jo imenujejo faza začetnega, sedanjega in razvijajočega odziva, se družina sooča $\mathrm{s}$ stalnimi zahtevami in izzivi, povezanimi z zdravstvenim stanjem otroka in tekočim zdravljenjem. Psihološki odzivi tako vztrajajo tekom zdravljenja in lahko pomembno vplivajo na samo sodelovanje otroka in družine ter sprožijo različne odzive na medicinske postopke in bolečino. $\mathrm{V}$ tej fazi akutnega zdravljenja je zelo pomembno obravnavanje zaznanih znakov pediatrične zdravstvene travme. Pri tem pa se je dobro zavedati, da so lahko odzivi in reakcije staršev in otrok na isti korak v zdravljenju zelo različni. Cilj na tej ravni je spremljanje družine in delovanje na nivoju kurative (Kazak idr., 2006).

Pri zadnji, tretji fazi, ki jo imenujejo faza dolgotrajnega odziva, se model osredotoča na pojavnost posttravmatske stresnih simptomov po zaključenem zdravljenju. Klinično je ta faza pomembna, saj dolgotrajna travma lahko pomembno vpliva na to, kako hitro družina poišče ponovno zdravniško pomoč ali pa se skuša ponovnemu zdravljenju izogniti. V tej fazi je še posebej pomembno pozornost posvetiti tudi staršem, ne samo otrokom, saj imajo lahko v posameznih primerih starši več težav (simptomov) kot otroci. Seveda pa so starši vključeni tudi v prvih dveh fazah. Ne smemo zanemariti vloge staršev, ki s svojimi odzivi in neposredno pomočjo pomembno vplivajo na sposobnost soočenja in na dolgoročno prilagojenostjo otrok na njihovo stanje (Kazak idr., 2006).

$\mathrm{V}$ literaturi se pojavlja nadgradnja in razširitev obstoječega modela, in sicer Integrativni usmerjeni model pediatričnega medicinskega travmatskega stresa (Slika 3; angl. Integrative trajectory model of pediatric medical traumatic stress). Model predpostavlja, da faze PMTS napredujejo glede na potek medicinskega dogodka in zdravljenja ter čas, v katerem se zgodita oziroma potekata. Medicinski dogodek in zdravljenje pa se razlikujeta glede na različne bolezni in motnje (Price idr., 2015).

Model preimenuje faze - peri-travma (angl. peri-trauma), akutna medicinska oskrba (angl. acute medical care) in nadaljnja oskrba ali zaključek oskrbe (angl. ongoing care or discharge from care). Tako kot osnovni model tudi $\mathrm{v}$ integrativnem ostaja odnos med medicinskim dogodkom in psihološkim odzivom posameznika osrednjega pomena in enako postavi subjektivno presojo kot eno izmed najmočnejših dejavnikov tveganja za razvoj PMTS. Otroci in starši, ki se soočajo z boleznijo, za katero je značilna visoka stopnja življenjske ogroženosti, ponovitvijo bolezni 
Slika 3

Integrativni usmerjeni model pediatričnega medicinskega travmatskega stresa (Price idr., 2015)

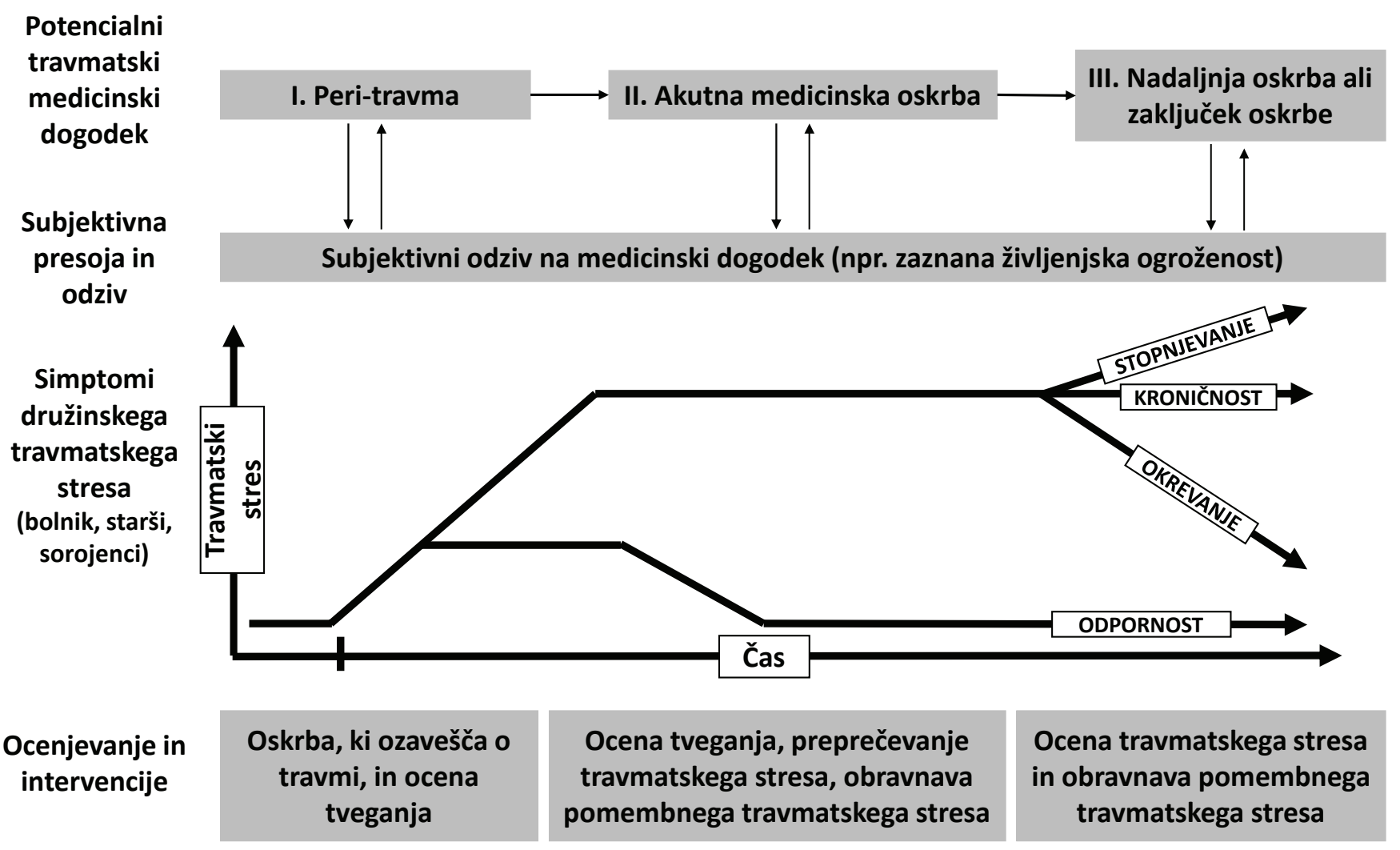

ali zapleti, vezanimi na pediatrično bolezen ali poškodbo, so podvrženi večjemu tveganju za razvoj medicinske travme (Price idr., 2015).

Model dodaja empirično podprte krivulje PMTS, in sicer predlaga štiri krivulje - odpornost oziroma prožnost (angl. resilient), okrevanje (angl. recovery), kroničnost (angl. Chronic) in stopnjevanje (angl. escalating) pediatričnega medicinskega travmatskega stresa, ki predstavljajo različne vzorce poteka PMTS skozi čas. Dodane krivulje poteka predstavljajo boljši vpogled $\mathrm{v}$ raznolikost psiholoških odzivov na pediatrične bolezni in poškodbe. Mnogo družin doživlja tipično in pričakovano stopnjo stresa kot odziv na pediatrično bolezen ali poškodbo. Omenjene družine predstavljajo krivuljo odpornosti oziroma prožnosti, kar poudarja sposobnosti prilagajanja večine otrok, njihovih staršev in sorojencev. Nekoliko manjši delež družin sledi krivulji okrevanja. Še manjši delež pa sledi krivulji kroničnost in stopnjevanja PMTS (Price idr., 2015).

Pri obravnavi PMTS model poudarja upoštevanje celotnega konteksta družine. Poleg tega nadgrajuje tudi ocenjevanje in intervencije, usmerjenje na preprečevanje, zmanjševanje in odpravljanje PMTS (Price idr., 2015).

\section{Intervencije in terapevtske možnosti}

V slovenskem zdravstvenem sistemu potrebujemo oskrbo, ki bo vključevala zavedanje in ozaveščanje o travmi (angl. trauma informed care) $\mathrm{z}$ namenom preprečevanja ponovne travmatiziranosti in zmanjševanja negativnih posledic, ki jih lahko ima zdravstvena obravnava za otroke in vključuje to razumevanje $\mathrm{v}$ organizacijsko kulturo, politiko in postopke. Tak pristop vključuje tudi razumevanje vpliva otrokove predhodne izpostavljenosti travmi (npr. nasilju, zlorabi in drugim, strah vzbujajočim izkušnjam) na trenutno zdravstveno stanje in odnos med zdravnikom ter otrokom in njegovo družino (Kassam-Adams in Butler, 2017). Pri tem je izrednega pomena, da prisluhnemo pacientom in njihovim družinam. Tako lažje razumemo njihove izkušnje in doživljanje ter prepoznamo morebitno prisotnost travme (Hall in Hall, 2016).

Odziv na travmatski dogodek ne vključuje samo negativnih posledic. Določeni odzivi na akutni stres predstavljajo prilagojen odziv in delujejo $\mathrm{v}$ funkciji obrambe, čeprav povzročajo vznemirjenje. V literaturi se ob tem pojavi pojem posttravmatske rasti (angl. posttraumatic growth), ki vključuje pozitivne posledice travmatskega dogodka. Posamezniki poročajo o pozitivnih spremembah v odnosu 
do sebe in v odnosih z drugimi (Kazak idr., 2006). Ta pojav je pogostejši pri otrocih, ki so se s pediatrično boleznijo ali poškodbo srečali po petem letu starosti.

Pomemben del intervencij je zgodnja in točna ocena tako kompetenc kot tudi rizičnih dejavnikov otroka in družine. Pri tem pa je pomembno, da so tako ocenjevanje kot tudi kasnejše intervencije prilagojene razvojnemu obdobju otroka. Prav tako je potrebno razširiti pogled na otroka v več kontekstih in vlogah (etnična pripadnost, kulturno okolje, vloga v družini, šoli ali vrtcu).

$\mathrm{V}$ predstavljenem modelu PMTS so intervencije razdeljene glede na posamezno fazo (Kazak idr., 2006). $\mathrm{V}$ prvi fazi, fazi peri-travme, so intervencije usmerjene na družino, namen pa je zmanjšati pomen potencialno travmatskih dogodkov, tako da podajamo informacije glede bolezni, diagnoze in poteka zdravljenja. Bistven in zelo pomemben cilj intervencij $\mathrm{v}$ tej fazi je povečati občutek varnosti in kontrole ter normalizirati čustvene odzive otroka in svojcev. Psiholog ima kompleksno nalogo, saj deluje kot povezovalni člen med zdravstvenim timom, katerega član je tudi sam, in družino. Družini nudi ustrezno psihološko podporo in vodi intervencije, usmerjene na družino, v obliki psihoedukacijskih programov, individualnih in skupinskih oblik pomoči za otroka, starše in sorojence. Zgodnja presoja prilagoditvenih spretnosti družine (stil spoprijemanja $\mathrm{s}$ stresom, funkcionalnost družine, stil vzgoje, morebitna psihopatologija) in njihovih zmožnosti obvladovanja nalog glede na stopnjo bolezni, socialno-ekonomsko ranljivost in osebno ali družinsko zgodovino, so ključnega pomena za nadaljnje psihološke intervencije.

V naslednji fazi, tekom intenzivnega zdravljena, je glavni cilj zmanjšati in preprečiti razvoj posttravmatskih stresnih simptomov (Kazak idr., 2006). Pri tem je potrebno najprej oceniti njihovo prisotnost in izraženost. V tej fazi so se kot najbolj učinkovite izkazale vedenjske tehnike, kot je priprava otroka na poseg, tehnike sproščanja, nagrajevanje vedenja, posnemanje modela, uporaba igre vlog in sistematična desenzitizacija. Pogosto se uporabljajo tudi kognitivne tehnike, kot so pozitivna samoregulacija, tehnike distrakcije, vizualizacija in učenje strategij reševanja problemov. Včasih je potrebno uvesti tudi medikamentozno terapijo, kadar so simptomi klinično pomembno izraženi in ovirajo posameznikovo vsakodnevno delovanje.

Po zaključenem zdravljenju je smiselno in potrebno otroka spremljati s kontrolnimi psihološkimi pregledi. Po potrebi in odvisno od izraženosti težav se otroka ali družino vključi tudi $\mathrm{v}$ psihoterapijo. $\mathrm{V}$ tej fazi psiholog aktivno sodeluje z zunanjimi inštitucijami, v največji meri s šolami ali vrtci, da se otroku zagotovi varno, spodbudno in prilagojeno okolje v vseh sistemih.

Na področju pediatrične obravnave so se kot najpogosteje uporabljene in najučinkovitejše izkazale vedenjsko kognitivna terapija, družinska terapija in igralna terapija (Nabors in Kichler, 2016). V tujini pa je trend oblikovanja preventivnih programov (Kazak idr., 2006), ki jih lahko izvaja celoten medicinski tim na oddelku.

\section{Zaključek}

Potreba po podpori otrokom in družinam, izpostavljenim akutnim in kroničnim zdravstvenim stanjem, je jasna in očitna. Medicinska znanost je $\mathrm{v}$ zadnjih desetletjih na področju pediatričnih bolezni, stanj in poškodb hitro napredovala. Vstopili smo v pomembno novo fazo zdravljenja pediatričnih življenjsko ogrožajočih bolezni, kar posledično spreminja celotno obravnavo. Naredili smo premik od zgolj tehničnega obvladovanja bolezni $\mathrm{k}$ prizadevanju za vzpostavljanje pogojev za kakovost življenja in duševno zdravje otrok ter njihovih družin. Vsi strokovni zdravstveni delavci si moramo prizadevati, da pediatrična obravnava in oskrba vključuje zavedanje in ozaveščanje o travmi. Travma se lahko pojavi pri katerem koli otroku, ki zboli za življenje ogrožajočo boleznijo, in njegovi družini ter negativno vpliva na njihovo vsakdanje delovanje. Avtorice tako ocenjujemo, da je mogoče in še kako potrebno pristopiti k vsakemu otroku in družini ter s tem zagotavljati psihološke intervencije, ki podprejo in spodbujajo duševno zdravje otrok, v primeru medicinske travme pa omogočijo psihološko rehabilitacijo.

\section{Literatura}

American Psychiatric Association. (2013). Diagnostic and statistical manual of mental disorders (5th ed.).

Ben-Ari, A., Benarroch, F., Sela, Y. in Margalit, D. (2019). Risk factors for the development of medical stress syndrome following surgical intervention. Journal of Pediatric Surgery, 55(9), 1685-1690.

Bokszczanin, A. (2007). PTSD symptoms in children and adolescents 28 months after a flood: Age and gender differences. Journal of Traumatic Stress, 20(3), 347-351.

Bronner, M. B., Knoester, H., Bos, A. P., Last, B. F. in Grootenhuis, M. A. (2008). Posttraumatic stress disorder (PTSD) in children after paediatric intensive care treatment compared to children who survived a major fire disaster. Child and Adolescent Psychiatry and Mental Health, 2(1).

Edmondson, D. (2014). An enduring somatic threat model of posttraumatic stress disorder due to acute life-threatening medical events. Social and Personality Psychology Compass, 8(3), 118-134.

Hall, M. F. in Hall, S. E. (2016). Managing the psychological impact of medical trauma: A guide for mental health and health care professionals. Springer Publishing Company.

Ingerski, L. M., Shaw, K., Gray, W. N. in Janicke, D. M. (2010). A pilot study comparing traumatic stress symptoms by child and parent report across pediatric chronic illness groups. Journal of Developmental and Behavioral Pediatrics, 31, 713-719.

Jones, C., Baxkman, C., Capuzzo, M., Flaatten, H., Rylander, C. in Griffiths, R. D. (2007). Precipitants of post-traumatic stress disorder following intensive care: A hypothesis generating study of diversity in care. Intensive Care Medicine, 33, 978-985. 
Kassam-Adams, N. in Butler, L. (2017). What do clinicians caring for children need to know about pediatric medical traumatic stress and the ethics of trauma-informed approaches? AMA Journal of Ethics, 19(8), 793-801.

Kazak, A. E., Kassam-Adams, N., Schneider, S., Zlikovsky, N., Alderfer, A. M. in Rourke, M. (2006). An integrative model of pediatric medical traumatic stress. Journal of Pediatric Psychology, 31(4), 343-355.

Kazak, A. E., Rourke, T. M., Alderfer, A. M., Pai, A., Reilly, F. A. in Meadows, T. A. (2007). Evidence-based assessment, intervention and psychosocial care in pediatric oncology: A blueprint for comprehensive services across treatment. Journal of Pediatric Psychology, 32(9), 1099-1110.

Levine, P. A. in Frederick, A. (1997). Waking the tiger, healing trauma. North Atlantic Books.

Levine, P. A. in Kline, M. (2018). Skupaj premagujmo travme in stres: Kako pri otrocih krepimo samozavest in psihično odpornost [Overcoming trauma and stress together: How to strengthen children's self-confidence and psychological resilience]. Mladinska knjiga.

Marsac, L. M., Kassam-Adams, N., Delahanty, L. D., Widaman, F. K. in Barakat, P. L. (2014). Posttraumatic stress following acute medical trauma in children: A proposed model of bio/psycho/social processes during the peri-trauma period. Clinical Child Family Psychological Review, 17, 399-411.

McCarthy, M. C., Ashley, D. M., Lee, K. J. in Anderson, V. A. (2012). Predictors of acute and posttraumatic stress symptoms in parents following their child's cancer diagnosis. Journal of Traumatic Stress, 25, 558-566.

Meiser-Stedman, R. A., Yule, W., Dalgleish, T., Smith, P. in Glucksman, E. (2006). The role of the family in child and adolescent posttraumatic stress following attendance at an emergency department, Journal of Pediatric Psychology, 31(4), 397-402.

Nabors, L. in Kichler, J. (2016). Play therapy with children experiencing medical illness and trauma. V K. O'Connor, C. Schaefer in D. B. Braverman (ur.), Handbook of play therapy (str. 437-454). John Wiley and Sons.

National Child Traumatic Stress Network. (2003). Medical Trauma. https://www.nctsn. org/what-is-child-trauma/trauma-types/medical-trauma

Nelson, P. L. in Gold, I. J. (2012). Posttraumatic stress disorder in children and their parents following admission to the pediatric intensive care unit: A review. Pediatric Critical Care Medicine, 13(3), 338-347.

Ostrowski, S. A., Christopher, N. C. in Delahanty, D. L. (2007). Brief report: The impact of maternal posttraumatic stress disorder symptoms and child gender on risk for persistent posttraumatic stress disorder symptoms in child trauma victims. Journal of Pediatric Psychology, 32(3), 338-342.

Pai, A. L. H., Greenley, R. N., Lewandowski, A., Drotar, D., Youngstrom, E. in Peterson, C. C. (2007). A meta-analytic review of the influence of pediatric cancer on parent and family functioning. Journal of Family Psychology, 21, 407-415.

Pai, A. L. H. in Kazak, E. A. (2006). Pediatric medical traumatic stress in pediatric oncology: Family system interventions. Current Opinion Pediatric, 18, 558-562.
Patino-Fernandez, A. M., Pai, A., Alderfer, M., Hwang, W., Reilly, A. in Kazak, A. E. (2007). Acute stress in parents of children newly diagnosed with cancer. Pediatric Blood Cancer, 50, 289-292.

Price, J., Kassam-Adams, N., Alderfer, M. A., Christofferson, J. in Kazak, A. E. (2015). Systematic review: A reevaluation and update of the Integrative (trajectory) model of pediatric medical traumatic stress. Journal of Pediatric Psychology, 41(1), 86-97.

Rees, G., Gledhill, J., Garralda, M. E. in Nadel, S. (2004). Psychiatric outcome following paediatric intensive care unit (PICU) admission: A cohort study. Intensive Care Medicine, 30(8), 1607-1614.

Rennick, J. E., Morin, I., Kim, D., Johnston, C. C., Dougherty, G. in Platt, R. (2004). Identifying children at high risk for psychological sequelae after pediatric intensive care unit hospitalization. Pediatric Critical Care Medicine, 5(4), $358-363$.

Rennick, J. E. in Rashotte, J. (2009). Psychological outcomes in children following pediatric intensive care unit hospitalization: A systematic review of the research. Journal of Child Health Care, 12(2), 128-149. 